\title{
Marek's Disease: rapid progress in research with unclear biological implementations
}

\author{
V. ZELNÍK, B. LAPUNÍKOVÁ, M. KÚDELOVÁ
}

Institute of Virology, Slovak Academy of Sciences, Dúbravská cesta 9, 84505 Bratislava, Slovak Republic

\begin{abstract}
Summary. - Here we would like to provide a brief overview of the modern history of Marek's disease (MD) research with a focus on the most recent developments in experimental work and we will try to sum up their impact on the understanding of the biological properties of Marek's disease type 1 (MDV-1), the only representative of the Mardivirus genus causing fatal lymphoproliferative disease in poultry. We will also compare MDV-1 with other serologically-related poultry herpesviruses, Marek's disease virus type 2 (MDV-2) and herpesvirus of turkeys (HVT). Although MD was first described at the beginning of the last century, proper characterization of its biological impact on poultry production and utilization of molecular biology methods for detailed characterization of causative agent MDV-1 were introduced only in recent decades. However, many characteristics of MD infection, pathogenesis and vaccine protection mechanisms remain unclarified, though novel methods bring a challenge for better understanding of these unanswered questions.
\end{abstract}

Keywords: Marek's disease; Marek's disease virus; lymphoproliferative neoplastic disease; Meq oncoprotein

\section{Contents:}

1. Overview of Marek's disease history

1.1 The importance of the 1960's and 70's in the introduction of modern techniques to the study of the biology of Marek's disease

2. Molecular pathogenesis of Marek's disease

2.1 Meq protein (MDV EcoRI-Q oncoprotein)

2.2 microRNAs (miRNAs) encoded by MDV-1

2.3 Transcripts expressed in the repeat regions of the MDV-1 genome

3. Vaccines against Marek's disease and their function

4. New genetic approaches to the study of Marek's disease and related viruses

E-mail: viruzelo@savba.sk; phone: +421-2-59302463.

Abbreviation: $\mathrm{BAC}=$ bacterial artificial chromosome; HSV-1 = herpes simplex virus 1 ; HVT $=$ herpesvirus of turkeys serotype 3; MeHV-1 = Meleagrid herpesvirus 1; MD = Marek's Disease; MDV-1 and 2 = Marek's disease virus type 1 and 2, GaHV-2 and 3 = Gallid herpesvirus 2 and 3; Meq = MDV EcoRI-Q oncoprotein; miRNA $=$ microRNA

\section{Overview of Marek's disease history}

The disease was primarily described as polyneuritis in chickens (Marek, 1907), and decades later named by its founder, Professor of the Department of Veterinary Medicine at the Hungarian Veterinary School, Jozsef Marek (from Horná Streda and currently residing in the Slovak Republic). The primary discovery however brought no deep interest in the scientific and poultry production fields as paralysis of the legs and wings was rather uncommon at that time. However awareness began to increase with the intensification of the poultry production business in the 1950's and 60's, when more avian pathogens began to pose a threat to the business itself with great losses in production. At this time, MD also became a serious problem when transformed lymphocytes began to be more invasive not just to the nervous system but also causing lymphoid tumours in visceral organs, mainly the spleen, Bursa Fabricius, thymus, liver, kidney, ovary, proventriculus and later, with more pathogenic strains in the heart and muscles also.

In the first half of the last century, there was confusion in relation to the aetiological causative agent of the lethal disease as neoplastic conditions of homeopathic system of 
domestic chickens were also described (Ellermann, 1921). In 1961 it was proposed by Biggs (1961) to differentiate in classification between lymphoid leucosis caused by retroviruses and fowl paralysis, later called MD.

The real breakthrough came in the late 1960's when the aetiological agent of MD was identified and characterized and new approaches to control the disease were introduced.

1.1 The importance of the 1960's and 70's in the introduction of modern techniques to the study of the biology of Marek's disease

Development of a cell culture system for propagation of MD causative agent using infectious blood or tumour tissues resulted in visible cytopathic effect in in vitro cultured chicken kidney cells (Churchill and Biggs, 1967) or duck embryo fibroblasts (Nazerian et al., 1968). These pioneering findings resulted in an increase in basic and molecular biological studies on MD and its causative agent Marek's disease virus type 1 (MDV-1) currently classified as Gallid herpesvirus 2 (GaHV-2). MDV-1 was found in both cases as strongly cell-associated in in vitro cell culture. The source of fully infectious, cell-free MDV-1 virus has been described only in chicken feather follicles (Calnek et al., 1970).

Soon after identification of the causative agent of MD, the first live attenuated vaccines against the disease were prepared by serial in vitro passage of mild HPRS-16 strain of MDV-1 (Churchill et al., 1969). This vaccine was soon replaced by serologically related herpesvirus of turkeys (HVT) currently classified as Meleagrid herpesvirus 1 (MeHV-1) which is apathogenic to chickens as well as to turkey (Okazaki et al., 1970; Witter et al., 1970).

The late 1960 's till the early 90 's brought about a significant breakthrough in molecular biology characterization of MDV-1 and serologically related apathogenic avian herpesviruses, Marek's disease virus type 2 (MDV-2) currently classified as Gallid herpesvirus 3 (GaHV-3) and HVT. Restriction enzyme maps and cloned fragments of their genomes were prepared (Gibbs et al., 1984; Hirai et al., 1979; Ross et al., 1983). Many fragments of MDV-1, MDV-2, and HVT genome were sequenced and found to be homologous to Alphaherpesviruses genes with similar co-localization mainly within the unique long $\left(U_{L}\right)$ or unique short $\left(U_{S}\right)$ parts of the respective genomes, e.g. as described in comparison with varicella-zoster virus by Buckmaster et al. (1988).

In past, all strains of virus originally designed as Marek's disease virus (MDV) were divided to serotypes 1-3 and also classified as so-called virulent (v), very virulent (vv), or very virulent plus (vv+) strains (Schat et al., 1982; Witter, 1997). Recent nomenclature reclassifies serotype 1 encompassing all pathogenic or oncogenic strains as GaHV-2, serotype 2 encompassing naturally non-pathogenic strains as GaHV-3, and serotype 3 encompassing non-oncogenic viruses isolated from turkeys as MeHV-1, respectively. They all are members of the Mardivirus genus (the Alphaherpesvirinae subfamily, the Herpesviridae family).

A "boom" in molecular characterization of MDV-1 occurred in the late 1990's and it is the fact that there is still big interest to study the disease.

It is of great importance to keep in mind that MDV-1 is an evolving pathogen. Despite the fact that it is a DNAencoded virus with lower frequency of mutations compared to RNA viruses, MDV-1 has been shown to be a pathogen which adapts to the environment even under conditions of preventive vaccination strategies. Under these conditions, mild MDV-1 that could have been prevented by HVT, underwent changes that resulted in the occurrence of very virulent $M D V-1$ strains resistant to HVT vaccination (Schat et al., 1982). Even after the introduction of bivalent $M D$ vaccines based on use of live apathogenic HVT and MDV-2 mixture, viruses of MDV-1 breaking the vaccine protection were isolated vaccine in 1990's (Witter, 1997). Whether extensive use of MD vaccines can drive MDV-1 to its increased virulence is up for discussion (Davison and Nair, 2005). It is clear that serial in vitro passage of MDV-1 causes attenuation of the virus with dynamic changes in its genome (Fukuchi et al., 1985; Kopacek et al., 1993; Silva et al., 1985). Although there is still a general feeling that we do not fully understand or have undermined the impact of these genetic changes on the biological properties of different MDV-1 isolates and their passage history, the recent results of some authors are opening new insights into this topic (Spatz et al., 2012).

\section{Molecular pathogenesis of Marek's disease}

As mentioned above, MD is a highly contagious neoplastic disease mostly affecting chickens but in some cases also turkeys. The main syndromes named under "classical" MD include neurolymhomatosis resulting in nerve paralysis and lymphatous infiltration as well as tumours in visceral organs, muscles and skin. New vv and vv+ MDV strains are even more aggressive, causing death in very young birds (reviewed by Calnek, 2001).

MD is certainly among a category of diseases with complex pathogenesis. These attributes relate mainly to the virulence of relevant MDV-1 strain, genetic background of the infected host and overall management of hygiene in animal houses. Nevertheless, with intensified poultry production, serologically related avian herpesviruses with different impacts on pathogenesis and/or protective potential have been reported and isolated (a summary of these Mardivirus genus isolates can be found in Table 1). 
Table 1. Mardivirus genus viruses characterized by their serotypes and pathotypes

\begin{tabular}{|c|c|c|c|c|}
\hline \multicolumn{3}{|c|}{ Virus } & \multirow{2}{*}{ Pathotype/clinical signs } & \multirow{2}{*}{ Representative isolates } \\
\hline Standard nomenclature & Serotype & Current classification & & \\
\hline \multirow[t]{4}{*}{$\begin{array}{l}\text { Marek's disease virus type } 1 \\
(\mathrm{MDV}-1)\end{array}$} & 1 & Gallid herpesvirus 2 (GaHV-2) & $\begin{array}{l}\text { vv+ MDV, very virulent plus MDV-1 } \\
\text { strains early age mortality caused by im- } \\
\text { munosuppression and failure of protection } \\
\text { by bivalent MDV- } 2 \text { + HVT vaccines }\end{array}$ & $\begin{array}{l}\text { 648A (Witter, 1997; Spatz et al., } \\
\text { 2012) }\end{array}$ \\
\hline & & & $\begin{array}{l}\text { vv MDV, very virulent MDV-1 strains/ } \\
\text { very low protection induced by HVT- } \\
\text { based vaccines }\end{array}$ & $\begin{array}{l}\text { Md5 (Tulman et al., 2000); } \\
\text { RB-1B (Schat et al., 1982) }\end{array}$ \\
\hline & & & v MDV, virulent MDV-1 strains & $\begin{array}{l}\text { HPRS-16 (Purchase and Biggs, } \\
\text { 1967); JM (Sevoian et al., 1962) }\end{array}$ \\
\hline & & & Low pathogenic MDV-1 strains & $\begin{array}{l}\text { CVI988/Rispens (Rispens et } \\
\text { al., 1972) }\end{array}$ \\
\hline $\begin{array}{l}\text { Marek's disease virus type } 2 \\
(\mathrm{MDV}-2)\end{array}$ & 2 & Gallid herpesvirus 3 (GaHV-3) & $\begin{array}{l}\text { Non-oncogenic MDV-2 serologically } \\
\text { related to MDV-1 }\end{array}$ & SB-1 (Schat and Calnek, 1978) \\
\hline $\begin{array}{l}\text { Turkey herpesvirus } \\
\text { (HVT) }\end{array}$ & 3 & $\begin{array}{l}\text { Meleagrid herpesvirus } 1 \\
(\mathrm{MeHV}-1)\end{array}$ & $\begin{array}{l}\text { Non-pathogenic herpesviruses isolated } \\
\text { from turkey, serologically related to MDV } \\
\text { viruses. }\end{array}$ & Fc126 (Okazaki et al., 1970) \\
\hline
\end{tabular}

Thanks to novel approaches in studies of molecular properties of $\mathrm{MD}$, we can predict and conclude the most prominent determinants in MD pathogenesis.

\subsection{Meq protein (MDV EcoRI-Q oncoprotein)}

Meq protein encoded by MDV-1 is a member of a Jun/ Fos oncogene protein family (Jones et al., 1992). Meq is a unique gene encoded by oncogenic strains of MDV-1 without homologous partners present in genomes of MDV-2 and/or HVT. It encodes for a 339 amino-acid protein highly expressed in MDV-induced tumours and lymphoblastoid cell lines. Meq protein is the strongest candidate oncoprotein, potentially associated with other factors, encoded by MDV-1.

It should be mentioned that there is also L-Meq gene presented in genomes of low pathogenic MDV-1 strains, e.g. CVI988/Rispens that have a 59 amino-acid proline-rich insert in the protein encoded (Lee et al., 2000). As proposed in some works, this might be an explanation as to why low pathogenic MDV-1 strains lack oncogenic potential typical for highly oncogenic MDV-1 viruses. For further analysis of Meq protein transformation potential, Rat-2 cells were transformed to over-express $\mathrm{Meq}$ resulting in the inhibition of apoptosis in the transformed cell line (Liu et al., 1998).

\section{2 microRNAs (miRNA) encoded by $M D V-1$}

miRNAs is a family of small RNA molecules that regulate gene expression at its post-transcriptional level.
The majority of large DNA viruses, mostly herpesviruses, encode their own miRNAs. Although the members of the Mardivirus genus encode their own set of miRNAs for each virus, there is significant evidence that MDV-1 encodes miRNAs that are related to MDV-1 pathogenesis. Primary studies indicated that these miRNAs flank to the Meq oncogene and/or map to latency-associated transcripts that are antisense to the immediate-early ICP4 gene (Burnside, et al., 2006). Stick et al. (2013) proposed that gga-miR-21 is upregulated during MDV-1 infection, indicating that Meq oncoprotein map to the relevant ggamiR-21 promoter of the TMEM49 gene. It was found that gga-miR-21 is overexpressed only upon infection with a very virulent $\mathrm{RB} 1-\mathrm{B}$ strain but not during infection with low pathogenic strain of MDV-1, CVI988/Rispens. There exists a great challenge to further explore the phenomenon of miRNAs in MD pathogenesis.

\subsection{Transcripts expressed in the repeat regions of $M D V-1$} genome

pp38 and related transcripts encoded within the region of the Bam HI-H restriction fragment of MDV-1 genome linking $U_{L}$ and terminal repeat long $\left(T_{L}\right)$ region of the MDV-1 genome were thought to be directly involved in oncogenicity and pathogenesis (Ross et al., 1993). The majority of references report to $132 \mathrm{bp}$ long repeats present within these regions that are multiplied during in vitro passage of the infectious virus (Silva and Barnett, 1991; Kopacek et al., 1993). However, it was clearly shown that 132 bp repeats 


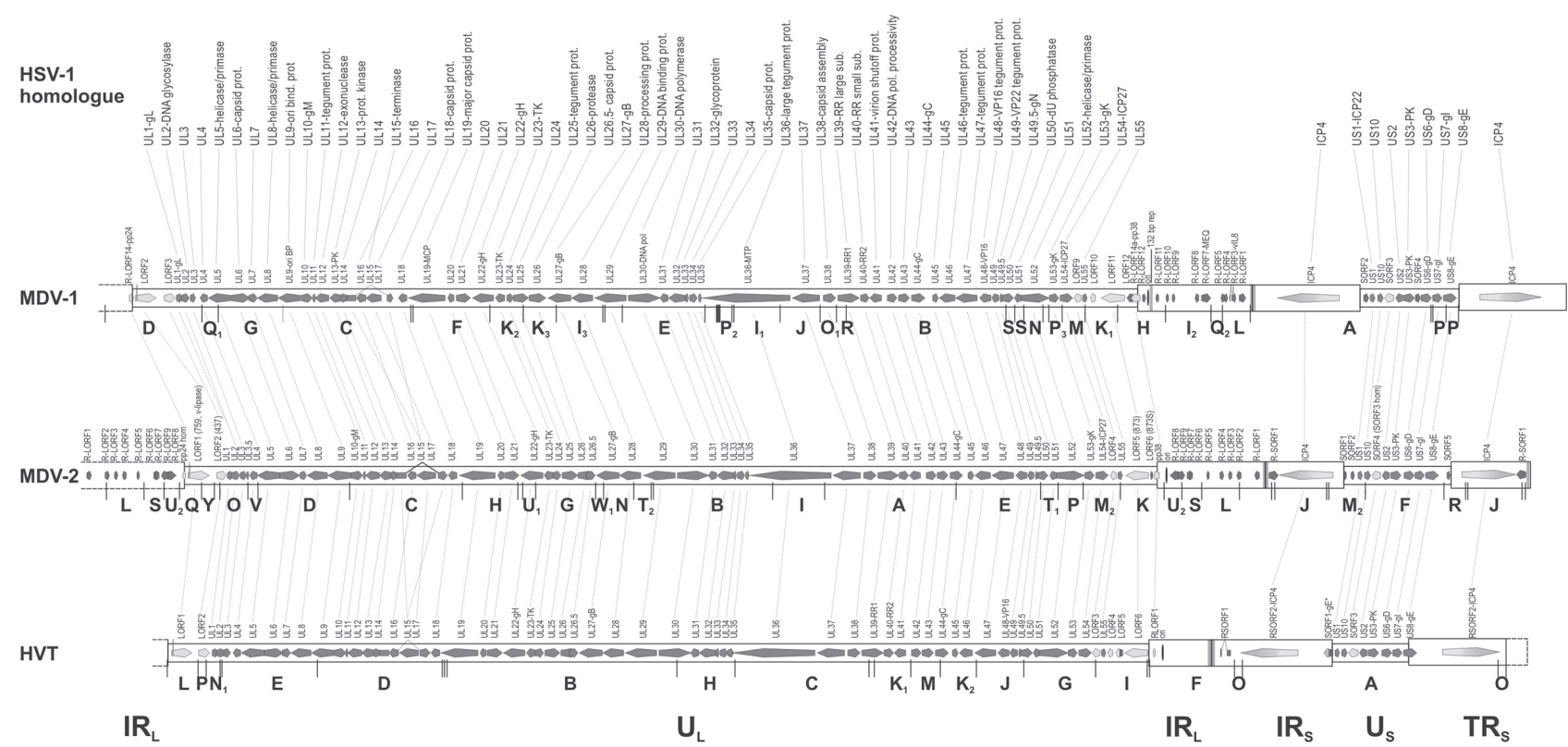

Fig. 1

Graphical comparative analysis of the genes layout in genomes of members of Mardivirus genus, Marek's disease virus type 1 (GaHV-2), Marek's disease virus type 2 (GaHV-3), and turkey herpesvirus (MeHV-1) modified according to Kingham et al. (2002) (References to the genomic sequences and their content in individual viruses can be find in the text)

expansions have no direct impact on MDV-1 oncogenesis (Silva et al., 2004).

However, in the region of $\mathrm{TR}_{\mathrm{L}}$ and internal repeat long $\left(\mathrm{IR}_{\mathrm{L}}\right)$ similarly as in terminal repeat short $\left(\mathrm{TR}_{\mathrm{S}}\right)$ and internal repeat short $\left(\mathrm{IR}_{\mathrm{S}}\right)$, there are also other important genomic elements and rather complex transcription that might have an impact on the replication and pathogenesis of MDV-1, e.g. lytic origin of replication (Camp et al., 1991), viral interleukin 8, (vIL8) (Engel et al., 2012), and/or MDV-1 -encoded telomerase (vTR) (Trapp et al., 2006) which has been shown to result in the loss of lymphomagenesis by introduction of mutations into its template sequence (Kaufer et al., 2011). Other important genes and transcripts have been described above.

\section{Vaccines against Marek's disease and their function}

The first available effective vaccine was created after isolation of the causative agent of MD, the strain HPRS-16 and was prepared by attenuation of the virus by serial in vitro passage (Churchill et al., 1969). Very soon after this pioneering MD vaccination achievement, serologically related herpesvirus, HVT was isolated from healthy turkeys which is apathogenic to chickens and to turkey also (Okazaki et al., 1970; Witter et al., 1970). However, with the increased virulence of MDV-1,
HVT became inefficient in protecting chickens against vv and $\mathrm{vV}+$ strains. In the early 1980's, a US bi-valent vaccine based on a mixture of HVT and apathogenic strain of MDV-2, strain SB-1 was introduced (Schat and Calnek, 1978). A vaccination based on HVT virus but also with a higher protective CVI988/Rispens vaccine whith apathogenic MDV-1 virus was successfully introduced in Europe (Rispens et al., 1972). The CVI988 vaccine virus was soon introduced to control MD in other parts of the world also. It is currently regarded as the most successful vaccine against MD but is generally the most effective vaccine for protection against oncogenic disease in veterinary practice (Witter and Kreager, 2004).

In the early 1980's new vaccination technology was introduced when embryonated eggs were in ovo immunized with live vaccines to protect hatched chickens from early infection caused by virulent MDV-1 (Sharma and Burmester, 1983).

Nevertheless, the function of MD vaccines remains unclear. It is certain that there is no early response against MDV by B cells promoting antibody protection, as there is clear evidence that reasonable antibody titres against MDV induced by $\mathrm{MD}$ vaccines are developed at the late stage of infection and are boosted by infectious MDV virus (Zelnik et al., 2004). The innate immune response and cytotoxic $\mathrm{T}$ lymphocytes are predominantly the main mediators of immune protection against MD (Schat and MarkowskiGrismund, 2001). 


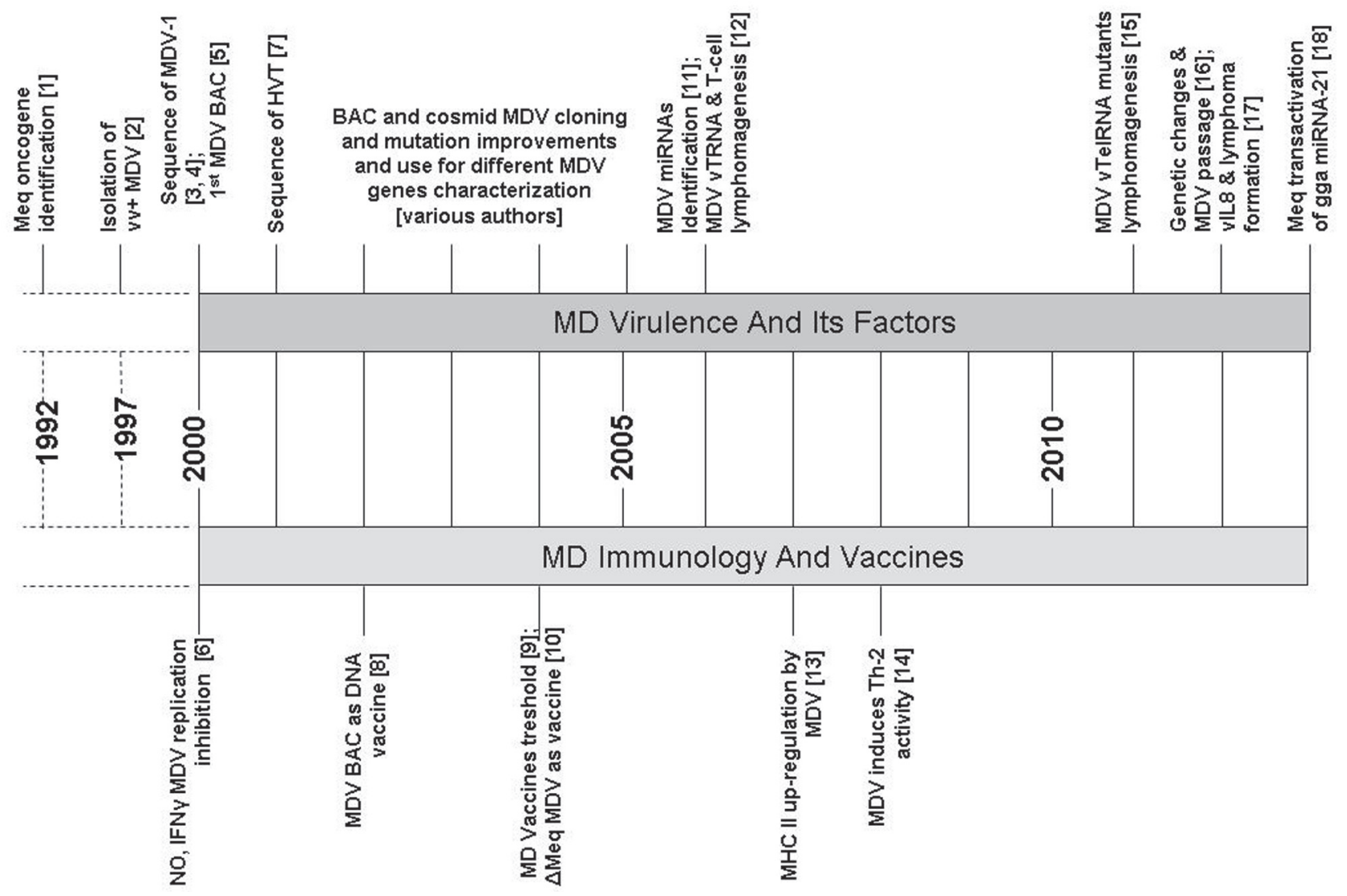

Fig. 2

Overview of selected the most current achievements in Marek's disease research

References in brackets respond to: [1] Jones et al., 1992; [2] Witter 1997; [3] Lee et al., 2000; [4] Tulman et al., 2000; [5] Schumacher et al., 2000; [6] Xing and Schat 2000; [7] Kingham et al., 2001; [8] Tischer et al., 2002; [9] Witter and Kreager 2004; [10] Lupiani et al., 2004; [11] Burnside et al., 2006; [12] Trapp et al., 2006; [13] Niikura et al., 2007; [14] Heidari et al., 2008; [15] Kaufer et al., 2011; [16] Spatz et al., 2012; [17] Engel et al., 2012; [18] Stik et al., 2013.

\section{New genetic approaches to the study of Marek's disease and related viruses}

Since the year 2000 new approaches have been taken to the genetic characterization of MDV-1. First of all, a full sequence of virulent MDV-1 (Lee et al., 2000; Tulman et al., 2000) and its serologically related HVT were published (Kingham et al., 2001). Gene layout of individual serologically related avian herpesviruses is graphically outlined in Fig. 1.

The real breakthrough in the study and characterization of MDV-1, MDV-2, and HVT genes and genetic elements came after introduction of bacterial artificial chromosome (BAC) technology (Schumacher et al., 2000; reviewed also in Zelnik, 2003). This novel approach also allowed for the preparation of an experimental DNA vaccine for the protection of chickens against MD (Tischer et al., 2002). The target of this minireview is not to describe all achievements resulting from the introduction of BAC technology to MD research. However a summary of these accomplishments since the introduction of this technology might be concluded in a separate review.

A brief summary on Marek's disease research with the most important outputs including timetable is provided in Fig.2.

Acknowledgements. This studies were supported by projects of Slovak Research Grant Agency, VEGA 02/0134/11 and VEGA 02/0091/13.

\section{References}

Biggs PM, Br. Vet. J. 117, 326-334, 1961.

Buckmaster AE, Scott SD, Sanderson MJ, Boursnell MEG, Ross NLJ, Binns MM, J. Gen. Virol. 69, 2033-2042, 1988. http:// dx.doi.org/10.1099/0022-1317-69-8-2033 
Burnside J, Bernberg E, Andersonn A, Lu C, Meyers BC, Green PJ, Jain N, Isaacs G, Morgan RW, J. Virol. 80, 8778-8786, 2006. Calnek BW, In Hirai K (Ed), Springer-Verlag Berlin, Heidelberg, pp. 32-41, 2001.

Calnek BW, Adlidnger HK, Kahn DE, Avian Dis.14, 219-233, 1970. http://dx.doi.org/10.2307/1588466

Camp HS, Coussens PM, Silva RF, J. Virol. 65, 6320-6324, 1991.

Churchill AE, Biggs PM, Nature 215, 528-530, 1967. 2004.

Churchill AE, Payne LN, Chubb RC, Nature 221, 744-747, 1969. http://dx.doi.org/10.1038/221744a0

Davison F, Nair V, Expert Rev. Vacc. 4, 1-12, 2004.

Ellermann V, Gyldendal, London, 1921.

Engel AT, Selvaraj RK, Kamil JP, Osterrieder N, Kaufer BB, J. Virol. 86, 8536-8545, 2012. http://dx.doi.org/10.1128/JVI.00556-12

Fukuchi K, Tanaka A, Schierman LW, Witter RL, Nonoyama M, Proc. Natl. Acad. Sci. USA 82, 751-754, 1985. http:// dx.doi.org/10.1073/pnas.82.3.751

Gibbs CP, Nazerian K, Velicer LF, Kung H-J, (1984): Proc. Natl. Acad. Sci. USA 81, 3365-3369, 1984. http://dx.doi. org/10.1073/pnas.81.11.3365

Heidari M, Zhang HM, Sharif S, Viral. Immunol. 21, 203-214, 2008

Hirai K, Ikuta K, Kato S, J. Gen. Virol. 45, 119-131, 1979. http:// dx.doi.org/10.1099/0022-1317-45-1-119

Jones D, Lee L, Liu J-L, Kung H-J, Tillotson JK, Proc. Natl. Acad. Sci. USA 89, 4042-45046, 1992. http://dx.doi.org/10.1073/ pnas.89.9.4042

Kaufer BB, Arndt S, Trapp S, Osterrieder N, Jarosinski KW, PLoS Pathogens 7, e1002333, 2011. http://dx.doi.org/10.1371/ journal.ppat.1002333

Kingham BW, Zelnik V, Kopacek J, Majerciak V, Ney E, Schmidt CJ, J. Gen. Virol. 82, 1123-1135, 2001.

Kopacek J, Ross LJN, Zelnik V, Pastorek J, Acta Virol. 37, 191-195, 1993.

Lee SI, Takaqi M, Ohashi K, Suquimoto C, Onuma M, J. Vet. Med. Sci. 62, 287-292, 2000. http://dx.doi.org/10.1292/ jvms.62.287

Lee FL, Wu P, Sui D, Ren D, Kamil J, Kung H-J, Witter RL, Proc. Natl. Acad. Sci. USA 97, 6091-6096, 2000. http://dx.doi. org/10.1073/pnas.97.11.6091

Liu J-L, Ye Y, Lee LF, Kung H-J, J. Virol. 72, 388-395, 1998.

Lupiani B, Lee LF, Cui X, Gimeno I, Anderson A, Morgan RW, Silva RF, Witter RL, Kung HJ, Reddy SM, Proc. Natl. Acad. Sci. USA 101, 11815-20. 2004.

Marek J, Deutsche Tierartzzeitung Wschr. 15, 417-421, 1907.

Nazerian K, Solomon JJ, Witter RL, Burmester BR, Proc. Soc. Exp. Biol. Med. 127, 177-182, 1968.

Niikura M, Kim T, Hunt HD, Burnside J, Morgan RW, Dodgson JB, Cheng HH, Virology 359, 212-219, 2007.

Okazaki W, Purchase HG, Burmester BR, Avian Dis. 14, 413-429, 1970. http://dx.doi.org/10.2307/1588488
Purchase HG, Biggs PM (1967): Res. Vet. Sci. 8, 440-449, 1967.

Rispens BH, von Vloten H, Mastenbroek N, Maas, HJL, Schat KA, Avian Dis. 16, 108-125, 1972. http://dx.doi. org/10.2307/1588905

Ross N, Binns MM, Sanderson M, Schat KA, Virus Genes 7, 33-51, 1993. http://dx.doi.org/10.1007/BF01702347

Ross LJN, Milne B, Biggs PM, J. Gen. Virol. 64, 2785-2790, 1983. http://dx.doi.org/10.1099/0022-1317-64-12-2785

Schat KA, Calnek BW, (1978): J. Nat. Cancer Inst. 60, 1075-1082, 1978.

Schat KA, Calnek BW, Fabricant J, Avian Pathol. 11, 593-605, 1982. http://dx.doi.org/10.1080/03079458208436134

Schat KA, Markowski-Grismund, In Hirai K (Ed), Springer-Verlag, Berlin, Heidelberg, New York, pp. 91-120, 2001.

Schumacher D, Tischer BK, Fuchs W, Osterrieder N, J. Virol. 74, 11088-10098, 2000. http://dx.doi.org/10.1128/ JVI.74.23.11088-11098.2000

Silva RF, Barnett JC, Avian Dis. 35, 487-495, 1991. http://dx.doi. org $/ 10.2307 / 1591212$

Silva RF, Reddy SM, Lupiani B, J. Virol. 78, 733-740, 2004. http:// dx.doi.org/10.1128/JVI.78.2.733-740.2004

Silva RF, Witter RL, J. Virol. 54, 690-696, 1985.

Sharma JM, Burmester BR, Avian Dis. 27, 453-463, 1983. http:// dx.doi.org/10.2307/1590171

Spatz SJ, Volkening JD, Gimeno IM, Heidari M, Witter RL, Virus Genes 45, 526-536, 2012. http://dx.doi.org/10.1007/ $\underline{\text { s11262-012-0792-Z }}$

Stick G, Dambrine G, Pfeffer S, Rassachaert D, J. Virol. 87, 80-93, 2013. http://dx.doi.org/10.1128/JVI.02449-12

Trapp S, Parcells MS, Kamil JP, Schumacher D, Tischer BK, Kumar PM, Nair VK, Osterrieder N, J. Exp. Med. 203, 1307-1317, 2006. http://dx.doi.org/10.1084/jem.20052240

Tischer BK, Schumacher D, Beer M, Beyer J, Teifke JP, Osterrieder K, Wink K, Zelnik V, Fehler F, Osterrieder N, J. Gen. Virol. 83, 2367-2376, 2002.

Tulman ER, Afonso CL, Lu Z, Zsak L, Rock DL, Kutish GF, J. Virol. 74, 7980-7988, 2000. http://dx.doi.org/10.1128/ JVI.74.17.7980-7988.2000

Witter RL, Avian Dis. 41, 149-163, 1997. http://dx.doi. org/10.2307/1592455

Witter RL, Kreager KS, Avian Dis. 48, 768-782, 2004. http://www. bioone.org/doi/abs/10.1637/7203-050304R-aff2\#aff2 http://dx.doi.org/10.1637/7203-050304R

Witter RL, Nazerian K, Purchase HG, Burgoyne GH, Am. J. Vet. Res. 31, 525-538, 1970.

Xing Z, Schat KA, Immunology 100, 70-6, 2000.

Zelnik V, Avian Pathol. 32, 323-333, 2003. http://dx.doi. org/10.1080/0307945031000121068

Zelnik V, Harlin O, Fehler F, Kaspers B, Göbel TW, Nair VK, Osterrieder N, J. Vet. Med., Ser. B 51, 61-67, 2004. 